Environnement urbain

Urban Environment

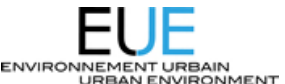

Villes arabes, villes durables? Enjeux, circulations et mise à

l'épreuve de nouvelles politiques urbaines

Arab Cities, Sustainable Cities? Challenges, movements and testing of new urban policies south of the Mediterranean

Pierre-Arnaud Barthel et Eric Verdeil

Volume 7, 2013

Villes arabes, villes durables? Enjeux, circulations et mise à l'épreuve de nouvelles politiques urbaines

Arab cities, sustainable cities? Challenges, movements and testing of new urban policies south of the mediterranean

URI : https://id.erudit.org/iderudit/1027722ar

DOI : https://doi.org/10.7202/1027722ar

Aller au sommaire du numéro

Éditeur(s)

Réseau Villes Régions Monde

ISSN

1916-4645 (numérique)

Découvrir la revue

Citer ce document

Barthel, P.-A. \& Verdeil, E. (2013). Villes arabes, villes durables? Enjeux, circulations et mise à l'épreuve de nouvelles politiques urbaines / Arab Cities, Sustainable Cities? Challenges, movements and testing of new urban policies south of the Mediterranean. Environnement urbain / Urban Environment, 7, III-VIII. https://doi.org/10.7202/1027722ar 


\title{
VILLES ARABES, VILLES DURABLES? ENJEUX, CIRCULATIONS ET MISE A L'EPREUVE DE NOUVELLES POLITIQUES URBAINES
}

\author{
LIMINAIRE
}

Le changement climatique, l'urbanisme écoresponsable et la maîtrise de la consommation énergétique sont autant de questions qui ont été érigées depuis quelques années en problèmes publics sur la rive sud de la Méditerranée, dont s'emparent non seulement élus et pouvoirs publics, mais aussi acteurs privés, société civile (ONG et associations) et acteurs internationaux présents dans les pays. Et les villes en tant qu'espaces concentrant désormais une part majeure de la population et de la consommation énergétique, et en tant que systèmes complexes d'acteurs institutionnels et économiques, sont des lieux très sensibles d'expérimentation du développement urbain durable (DUD). Ainsi, la question de la diffusion de cette nouvelle injonction depuis au moins les années 2000 du côté sud de la Méditerranée est posée dans ses modalités, ses nécessaires adaptations et appropriations.

Ce numéro ne vise pas à identifier la vulnérabilité environnementale des villes arabes, ni à dresser l'inventaire des institutions en charge, à l'échelle nationale, du développement durable. II met plutôt l'accent sur les mobilisations et les projets se revendiquant, à l'échelle d'une ou plusieurs villes, de la problématique du développement urbain durable. II porte sur les mots d'ordre et sur les formes de mobilisation un regard critique (théoriquement aussi bien que politiquement), à partir de plusieurs axes de questionnement.

Les contributions réunies ici prolongent une réflexion ouverte par un réseau de chercheurs français et issus des pays des rives sud et est de la Méditerrannée, dans un colloque organisé en 2010 (Barthel, Zaki 20II), et poursuivie dans le cadre d'une recherche financée principalement par l'Agence universitaire de la francophonie (AUF 2010/2012-programme Mersi : « Ville durable au Sud de la Méditerranée »). En sollicitant la revue Environnement urbain, il s'agit en outre d'élargir le débat en direction d'autres chercheurs ne participant pas à ce programme. Résultat de la sélection opérée par le comité de rédaction de la revue, le numéro regroupe trois articles proposant des éléments de synthèse des réflexions du réseau cité, complétés par cinq autres articles en provenance d'horizons divers, témoignant de l'actualité de la thématique en question.

Une tentative de lecture transversale des questionnements abordés par les différents auteurs conduit à identifier quatre thématiques. La première renvoie à la géographie du développement urbain durable au sud et à l'est de la Méditerranée, pour laquelle le numéro apporte des enseignements particulièrement riches. II fait apparaître une géographie structurée par la circulation des idées et des pratiques, mais aussi marquée par des espacesclés qu'on peut repérer à différentes échelles. André Donzel souligne fortement que l'espace méditerranéen constitue un espace d'échanges d'expériences, notamment entre métropoles. Ces circulations sont permises par un complexe entrelacs d'institutions, d'acteurs et de financements, au premier rang desquels les initiatives de I'Union européenne dans la foulée du Processus de Barcelone. Mais plus largement elles s'inscrivent dans des réseaux humains universitaires ou professionnels existants entre les deux rives de la Méditerranée. Toutefois, l'analyse par Amélie Pinel de la généalogie du système de bus à haut niveau de service (BHNS), actuellement en projet à Amman, met en valeur d'autres cheminements, plus complexes, entre initiative brésilienne, répliques en pays émergents et expertises des bailleurs de fonds internationaux ou occidentaux. 
La Tunisie apparaît surreprésentée dans ce dossier: c'est sans doute un effet du hasard mais cela renvoie aussi à la posture pionnière de ce pays à l'égard de la thématique environnementale, comme le rappelle la généalogie de ses politiques en faveur du développement durable (Bennasr, Megdiche, Verdeil ; Kahloun) comme de la maîtrise de l'énergie (Benalouache) dans les articles retenus. Pour autant, si le volontarisme tunisien en la matière n'est pas niable, les bilans thématiques dressés par les articles font apparaître des limites notamment liées au contrôle politique étroit par l'Etat des acteurs impliqués, ainsi que l'instrumentalisation politique permanente de cette thématique pour la légitimité du régime autoritaire aujourd’hui déchu.

Le numéro apporte également un éclairage intéressant sur la spatialisation de ces politiques de développement durable. En première analyse, les articles confirment la place privilégiée des capitales politiques comme lieux de déploiements de ces mobilisations et expérimentations est indéniable : Amman en Jordanie (Pinel), la conurbation RabatCasablanca, Le Caire ou Damas (Barthel, Clerc, Philifert), Tunis (Benalouache, Kahloun). Pour autant, les autres textes montrent que des localités de second rang dans la hiérarchie urbaine, telles que Sfax en Tunisie (Donzel; Bennasr et al.) ou Tripoli au Liban (Farah) se retrouvent également sur la carte du développement urbain durable, au moins sur le plan des intentions. De même, le bilan des expériences d'Agendas 2I locaux en Tunisie (Kahloun) ou des initiatives municipales dans le domaine de l'environnement au Liban (Farah) mettent à l'honneur de petites localités de banlieue ou des villes provinciales petites et moyennes éloignées des grands centres qui montrent, au moins sur le plan rhétorique mais aussi surement, à travers des initiatives concrètes même si elles sont modestes, une véritable diffusion du DUD à des échelles parfois négligées par la recherche.

Une deuxième manière de lire ce dossier est de s'intéresser aux objets par lesquels les politiques du DUD sont mises en œuvre. Trois d'entre eux sont particulièrement cités: la planification urbaine, renouvelée par la planification stratégique (Donzel ; Bennasr et al.) ou les Agendas 21 locaux (Kahloun); les transports propres, notamment avec l'exemple encore inachevé - du BHNS à Amman (Pinel) ou l'énergie avec les programmes ambitieux de la Tunisie en faveur de la production électrique par panneaux photovoltaïques ou les chauffe-eaux solaires (Belanouache). L'émergence de nouveaux standards de la construction, parfois à l'échelle d'éco-quartiers ou de «villes vertes» comme au Caire ou à Casablanca, Rabat et Benguérir (Maroc), est également à l'agenda mais au-delà de quelques projets dont plusieurs restent sur le papier, le bilan reste modeste et quelque peu incantatoire, sinon de nature purement promotionnelle (Barthel et al.). Ces objets sont parties intégrantes de technologies et d'approches standards. Les textes retenus n'apportent pas d'information sur des mobilisations ou des expériences concernant par exemple les vertus durables des tissus urbains traditionnels. Les pays et les villes de la région ne semblent pas des sites d'innovation particuliers. En revanche, la crainte souvent énoncée (Mancébo, 20II) d'une dérive du DUD par une prise en compte privilégiée des enjeux globaux, tels que le changement climatique, au détriment de l'amélioration de l'environnement et des conditions de vue locales, ne doit pas être exagérée. En effet, les «petites" mobilisations évoquées par Kahloun ou Farah ou la volonté d'une reconquête du littoral à Sfax (Bennasr et al.) s'inscrivent bien à l'échelle des villes à l'environnement longtemps sacrifié par la rapidité de l'urbanisation ou la priorité donnée à l'industrie.

Un troisième enjeu est celui de la manière dont l'action publique est transformée par le DUD. Ce dernier fait l'objet de nombreuses attentes relatives à la transversalisation de l'action publique, ainsi qu'à une élaboration des politiques publiques plus concertée, participative voire démocratique. A cet égard, le rôle central joué par les Etats (ministères et agences nationales ad hoc) dans l'institutionnalisation du DUD (Barthel et al. ; Kahloun ; Bennasr et al.) a plutôt conduit à la reproduction des logiques préexistantes, hiérarchiques, top-down, expertes notamment sur les thématiques des énergies renouvelables, de l'industrie propre, de l'écoconstruction. Néanmoins, plusieurs exemples soulignent quand même le poids pris dans ces nouvelles politiques par des autorités municipales ou métropolitaines, souvent appuyées par l'assistance internationale cherchant explicitement à soutenir une action publique plus décentralisée. C'est le cas avec la Municipalité du Grand Amman (Pinel), avec le Schéma de Développement du Grand Sfax (SDGS), appuyé sur une coopération intermunicipale inédite - quoique non institutionnalisée - en Tunisie (Bennasr et al.), ainsi qu'avec un certain nombre d'exercices d'élaboration d'Agendas locaux en Tunisie (Kahloun). Pour autant, ces démarches nouvelles font preuve de nombreuses fragilités, sans s'avérer toujours très durables, au sens premier du terme. En Jordanie, le dispositif de préparation du projet de BHNS butte sur une contestation ouverte 
qui révèle en creux son incapacité à prendre en compte les attentes des catégories les plus en demande d'une offre de mobilité alternative. A Sfax, une ouverture réelle en direction de la société civile du processus d'élaboration a eu lieu pour le SDGS mais elle a été subtilement encadrée par l'Etat, et n'a jamais remis en cause les domaines d'action éminents de ce dernier. Dans de nombreux agendas 2I locaux tunisiens, on constate un processus similaire, voire une instrumentalisation des documents au bénéfice de certains cadres politiques locaux de l'ancien régime. L'article de Daher développe dans cette perspective une argumentation importante à prendre en compte, même si ses études de cas renvoient finalement moins à des politiques urbaines liées à l'environnement urbain au sens étroit et plus aux enjeux sociaux et politiques du tournant néolibéral (il questionne néanmoins la "social sustainability" des projets qu'il examine, ce qui est un volet essentiel de la durabilité. Analysant le néolibéralisme comme "discours" et proposant pour cela un utile cadre d'analyse, il souligne à quel point les transformations de l'action urbaine reproduisent des formes de domination et constituent, en se renouvelant, de nouvelles sphères du capitalisme. Si cette question n'a pas été traitée directement dans les articles de ce numéro, c'est évidemment une hypothèse centrale dont la mise à l'épreuve doit guider de prochaines recherches.

Le déclenchement des révoltes dans le monde arabe depuis 201I interroge les politiques de DUD analysées dans ce numéro. Ces dernières, avec les tentatives de renouvellement de l'action publique qu'on vient d'évoquer, représentaient-elles le début d'un changement dans les modes de faire de l'action collective préfigurant le bouillonnement soudain qui a emporté les régimes de Ben Ali et de Moubarak et qui défie, à des degrés divers, les pouvoirs en place au Maroc, en Jordanie ou en Syrie? Cette hypothèse, proposée notamment à propos de l'exemple égyptien (Barthel, Monqid 201 I; Barthel, Monqid éds., 201 I), est hardie et le recul manque pour une réponse assurée. Et les années $201 \mathrm{l}$ et 2012 ont été davantage marquées par une reconduction des chantiers en cours, même si les nouvelles majorités politiques ont changé à l'échelle des pays: les méga-projets sont toujours perçus comme une opportunité majeure de développement et d'emploi, les villes nouvelles sont maintenues comme solution au développement urbain, tandis que l'éradication «à l'aveugle» des quartiers informels perdure sous de nombreuses formes. La prise de distance par les nouveaux pouvoirs islamistes semble finalement encore bien faible par rapport à l'héritage des années précédant 2011 . Tout au plus, comme l'exemple tunisien le suggère, le marketing du développement durable (ses «boulevards de l'environnement» et autres « avenues de la qualité urbaine ») créé par le régime de Ben Ali a été bel et bien abandonné. Le développement durable y apparaît même dans le contexte actuel secondaire par rapport à d'autres demandes sociales au cœur des contestations, notamment portées par les syndicats, autour de la question de l'emploi. Les incantations au DUD paraissent se figer et les documents élaborés en son nom resteront peut-être lettre morte, traces de papier fragiles bientôt dispersées et égarées (Kahloun). En ce sens, cette thématique n'a-t-elle pas été un leurre, y compris pour les chercheurs? Pourtant, on peut aussi arguer que les militants du DUD, en Egypte comme en Tunisie, sont de ceux qui placent désormais parmi leurs revendications premières l'exigence d'une démocratisation véritable de l'action publique locale. Le DUD aurait-il alors été comme une chrysalide protégeant la croissance d'un fruit inattendu, et rendant possible une mue majeure des villes de cette région du monde? Le nouveau contexte représente à coup sûr pour les habitants des villes, les professionnels et les responsables politiques une promesse autant qu'un défi. Et pour la recherche, une nouvelle stimulation à rapprocher l'étude des politiques urbaines des mutations plus larges des sociétés.

\section{BIBLIOGRAPHIE}

BARTHEL P.-A., MONQID S. (eds.) (20II), "Le développement durable au Caire : une provocation?", Égypte/Monde arabe, third series, no..8, http://ema.revues.org/index2966.html

BARTHEL P.-A., MONQID S. (20II). Le Caire : réinventer la ville, Paris, Autrement (Collection Villes en mouvement).

BARTHEL P.-A., ZAKI L. (eds) (20II). Expérimenter la " ville durable " au sud de la Méditerranée. Chercheurs et professionnels en dialogues, (Villes et territoires). La Tour d'Aigues, Editions de l'Aube.

MANCEBO F. (20II). "La ville durable est-elle soluble dans le changement climatique?", Environnement urbain, vol. 5, p. I-9.

\section{Pierre-Arnaud BARTHEL, Guest Editor}

Eric VERDEIL, Guest Editor 


\title{
Arab Cities, Sustainable Cities? ChALlenges, MOVEMENTS AND TESTING OF NEW URBAN POLICIES SOUTH OF THE MEDITERRANEAN
}

\author{
INTRODUCTORY NOTE
}

The fight against climate change, eco-responsible urban development and the control of energy consumption have emerged as pressing public issues on the southern coast of the Mediterranean over the past several decades. Politicians and public authorities as well as private actors, civil society organizations (NGOs and the voluntary sector) and international bodies present in the countries of this region have all engaged with these challenges, which are particularly pronounced in cities. As spaces, cities now account for the bulk of the population and energy consumption; and as complex systems of institutional and economic actors, they are highly sensitive loci for experiments in sustainable urban development (SUD). Subsequently, the methods, applications and adaptation measures required for meeting this new imperative have been under discussion since the early 2000 s, if not earlier.

The aim of this thematic issue is to examine the activities and projects underway to promote sustainable urban development, be it at the scale of one or several cities. Thus, our focus is not to describe the environmental vulnerability of Arab cities, nor to draw up an inventory of the national institutions responsible for sustainable development. Our study takes a critical look, both theoretical and political, and from different perspectives, at the key arguments and the various forms of mobilization.

The eight contributions collected here build on ideas developed by a network of researchers from France and from southern and eastern Mediterranean countries at a colloquium held in Hammamet, Tunisia in 2010 (Barthel, Zaki 20l I) and pursued through research funded primarily by the Agence universitaire de la francophonie (AUF
2010/2012-Mersi programme: Ville durable au Sud de la Méditerranée). By publishing these contributions in an issue of the Environnement urbain journal, we hope to widen the debate to researchers outside of this program. The selection of papers was made by the journal's editorial committee and comprises three articles which provide a kind of synthesis of the ideas of the above network, plus five others from authors from various locations reflecting the current topics of this theme.

An attempt to read across the issues tackled by the different authors identifies four themes. The first relates to the geography of sustainable urban development to the south and east of the Mediterranean. It shows a geography structured by the circulation of ideas and practices, but also marked by key spaces that can be identified at different scales. André Donzel lays stress on the fact that the Mediterranean is an area characterized by the exchange of experience, in particular between cities. These interchanges are made possible by an interwoven complex of institutions, actors and funding bodies, headed by European Union initiatives arising from the Barcelona Process. More broadly, however, they are embedded in human networks, both academic and professional, which span the two sides of the Mediterranean. Further, the analysis by Amélie Pinel of the development of the Bus Rapid Transit (BRT) system currently being planned in Amman examines the complex process of SouthSouth transfer, in this case from Brazil to Jordan, with the assistance of international or Western funding agencies. 
Tunisia would seem to be overrepresented in this number. While this is perhaps a matter of chance, it may also be a reflection of the country's pioneering approach to environmental themes, as evidenced by the development of its policies in favour of sustainable development (Bennasr, Megdiche, Verdeil; Kahloun) and energy management (Benalouache). Nonetheless, while Tunisia has undoubtedly demonstrated a commitment to sustainability, the articles also reveal limitations, arising in particular from the State's tight political control of the actors involved as well as the nowdefunct authoritarian regime's constant political exploitation of this topic.

The journal also casts an interesting light on the spatial distribution of sustainability policies. On a first reading, the articles confirm the special role of political capitals as places where such policies are implemented and tested: Amman in Jordan (Pinel), the Rabat-Casablanca conurbation, Cairo or Damascus (Barthel, Clerc, Philifert), and Tunis (Benalouache, Kahloun). Nonetheless, the other texts show that cities lower down in the urban hierarchy, such as Sfax in Tunisia (Donzel; Bennasr et al.) or Tripoli in Lebanon (Farah) are also on the sustainable urban development map, at least as regards intentions. Similarly, the findings for local Agenda 21 experiments in Tunisia (Kahloun) or municipal environmental initiatives in Lebanon (Farah) put the spotlight on small suburban localities or small and medium-sized provincial towns away from the big centres. This demonstrates, at least on the rhetorical front, but also through practical albeit modest initiatives, the genuine spread of SUD to scales sometimes neglected by research.

A second way to read this feature is to look at the measures through which SUD policies are implemented. Three in particular are identified: I) urban planning, reinforced by strategic planning (Donzel; Bennasr et al.) or local Agenda 21 programs (Kahloun); 2) clean transport, notably with the still unfinished case of the BRT in Amman (Pinel); and 3) energy, with Tunisia's ambitious programs for power production by photovoltaic panels or for solar water heaters (Benalouache). The emergence of new building standards, sometimes within econeighbourhoods or "green cities," as in Cairo or in Casablanca, Rabat and Benguérir (Morocco), was also identified as a further possible measure. However, most projects initiated in this regard are either still on the drawing board or appear to serve merely token and promotional purposes (Barthel et al.). These approaches all involve standard technologies and methodologies. The selected texts give no information on initiatives or experiments on, for example, the sustainable qualities of traditional urban fabrics. The countries and cities of the region do not seem to have incubated any particular innovations. On the other hand, the oft- expressed fear (Mancebo, 20II) that the focus on SUD will eventually result in an excessive emphasis on global issues, such as climate change, to the detriment of improvements to the local environment and living conditions, should not be exaggerated. Indeed, the "small" initiatives described by Kahloun or Farah or the aspiration to reclaim the seafront at Sfax (Bennasr et al.) are well-suited to the scale of cities whose environment has long been sacrificed to rapid urbanization or industrial priorities.

A third question is how public action has been transformed by SUD. This process has raised expectations with regard to the potential development of cross-cutting public action and the emergence of more consultative, participatory, if not to say democratic, public policies. In this respect, the key role played by central government (ministries and ad hoc national agencies) in the institutionalization of SUD (Barthel et al.; Kahloun; Bennasr et al.) has instead led to a replication of existing hierarchical, top-down, expert approaches, in particular on the themes of renewable energy, clean industry and eco-construction. Nonetheless, several examples highlight the influence of municipal or metropolitan authorities in these new policies which are often supported by international partners that explicitly seek to support more decentralized public action. This is the case with the Municipality of Greater Amman (Pinel), with the Greater Sfax Development Strategy (SDGS) (Bennasr et al.), with an unprecedented intermunicipal-though noninstitutional-cooperation in Tunisia (Bennasr et al.), as well as a certain number of local plan initiatives in Tunisia (Kahloun). All the same, these new approaches remain fragile in many ways and are not always sustainable in the original sense of the term. In Jordan, the lead-up process to the BRT project has run into open opposition, revealing its shortcomings in taking account of the segments of the population most in need of alternative transport provision. In Sfax, there was genuine openness on the part of civil society to engage in the development of the SDGS. However, this willingness was subtly controlled by State, which maintained its preeminence in all spheres of intervention. In many local Tunisian Agenda 2l schemes, we find a similar phenomenon, and even exploitation to the benefit of some of the former regime's local cadres. In this 
respect, Daher's article develops an important argument, although his case studies ultimately relate less to strictly environment-related urban policies and more to the social and political consequences of the neoliberal shift. He nevertheless questions the "social sustainability" of the projects he examines, which is an essential facet of sustainability. Analyzing neoliberalism as a "discourse" and providing a useful analytical framework for this purpose, he highlights the extent to which the transformations of urban action reproduce the dynamics of domination and, as they are renewed, come to constitute new spheres of capitalism. While this question is not covered directly in the articles in this issue, it is obviously a key hypothesis that needs to be tested in future research.

The revolts and revolutions that have swept the Arab world since $201 \mathrm{I}$ give rise to assumptions, or hypotheses, about the SUD policies explored in this issue. One is that these policies, with their tentative shift toward the new kind of public action just described, constituted the start of a change in the methods of collective action that later culminated in the upheavals that toppled the regimes of Ben Ali and Mubarak and that threatened the structures in place in Morocco, Jordan or Syria. This hypothesis, postulated in particular with regard to Egypt (Barthel, Monqid 20II; Barthel, Monqid eds., 20I I), is a bold one and only time will tell if it is correct. Moreover, the years $201 \mathrm{I}$ and 2012 were marked more by the continuation of existing processes, despite the change in political majorities across countries. Thus, mega-projects are still perceived as a major opportunity for development and employment, new towns are still seen as a solution for urban development, while the "blind" eradication of shantytowns continues in numerous forms. The new Islamist authorities ultimately seem to have done little to distance themselves from the legacy of the years before 20ll. At best, as the Tunisian example suggests, the simplistic marketing of sustainable development (its "environmental boulevards" and other "avenues of urban quality") by the Ben Ali regime has been entirely abandoned. In fact, at present sustainable development seems to have dropped in priority given the many social demands made by the protests, in particular union demands relating to employment. In that context, calls for SUD seem to have become mere tokens, with draft documents most likely remaining on the drawing board, soon to be scattered and vanish (Kahloun). In this respect, SUD may well have been a red herring, even for the researchers. Yet it could also be argued that SUD activists, be it in Egypt or in
Tunisia, are among those whose primary claims now include the demand for a real democratization in local public action. In this case, SUD may well have been a chrysalis that protected the growth of an unexpected fruit, a foretaste of major change in the cities of this part of the world. The new conditions undoubtedly represent an opportunity as much as a challenge for city dwellers, professionals and politicians. And for research, they represent a new incentive to relate the study of urban policies to wider societal changes.

\section{BIBLIOGRAPHIE}

BARTHEL P.-A., MONQID S. (eds.) (20II), "Le développement durable au Caire : une provocation?", Égypte/Monde arabe, third series, no..8, http://ema.revues.org/index2966.htm

BARTHEL P.-A., MONQID S. (20II). Le Caire : réinventer la ville, Paris, Autrement (Collection Villes en mouvement).

BARTHEL P.-A., ZAKI L. (eds) (20II). Expérimenter la " ville durable » au sud de la Méditerranée. Chercheurs et professionnels en dialogues, (Villes et territoires). La Tour d'Aigues, Editions de l'Aube.

MANCEBO F. (20II). "La ville durable est-elle soluble dans le changement climatique?", Environnement urbain, vol. 5, p. I-9.

Pierre-Arnaud BARTHEL, Rédacteur invité

Eric VERDEIL, Rédacteur invité 